SOIENTIFIC JOURNALS AND ARTIOLES

The American Journal of Science, for August, contains the following articles:

E. T. Allen and J. K. Clement: "Rôle of Water in Tremolite and Other Minerals."

G. C. Ashman: "Quantitative Determination of the Radium Emanation in the Atmosphere."

R. W. LANGLEY: "Determination of Small Amounts of Barium in Rocks."

W. G. Mrxter: "Heat of Combination of Acidic Oxides with Sodium Oxide and Heat of Oxidation of Chromium."

I. K. Phetps and L. H. WeEd: "Concerning Certain Organic Acids and Acid Anhydrides as Standards in Alkalimetry and Acidimetry."

I. K. Phelps and L. H. Weed: "Comparison between Succinic Acid, Arsenious Oxide and Silver Chloride as Standards in Iodimetry, Acidimetry and Alkalimetry."

W. E. Ford and E. W. TrlLotson, JR.: "Orthoclase Twins of Unusual Habit."

J. V. LewIS: "Palisade Diabase of New Jersey."

F. B. Loomrs: "New Horse from the Lower Miocene."

THE contents of The Auk, for July, are as follows :

E. S. CAMERON: "Observations on the Golden Eagle in Montana."

J. H. RILEY: "Notes on the Broad-winged Hawks of the West Indies, with Description of a New Form."

Richard C. Harlow: "Recent Notes on Birds of Eastern Pennsylvania."

C. J. Pennock: "Birds of Delaware-Additional Notes."

J. A. ALLEN : "The Case of STRIX vs. ALUCO."

EDward J. Court: "Treganza Blue Heron."

Francis H. Allen: "Larus kumlieni and other Northern Gulls in the Neighborhood of Boston."

J. A. Allen: "Columbina versus Chomepelia."

James H. Fleming: "The Destruction of Whistling Swans (Olor columbianus) at Niagara Falls."

Austin Hobart Clark: "The Macaw of Dominica."

\section{TYPES OF AMERICAN GRASSES}

UNDER this title, Mr. A. S. Hitchcock has recently published in "Contributions from the U. S. National Herbarium," Vol. 12, Pt. 3 , the results of his studies of the types of
American grasses described by Linnæus, Gronovius, Sloane, Swartz and Michaux. These studies were made by $\mathrm{Mr}$. Hitchcock in the spring of 1907, at which time he made a detailed examination of American grasses preserved in the larger herbaria of Europe.

The contribution is a noteworthy one and will go far toward fixing names for the American grasses discussed, not alone specifically, but probably in some cases generically as well. The preservation of grass specimens is in most cases satisfactory as they are little subject to insect depredation. In a large majority of instances, Mr. Hitchcock found the type specimen readily and certainly identifiable; in some instances where the author had confused two or more species under one, he was obliged to consider each case upon its merits, and he has presented the evidence on which the type specimen was selected by him. In a few of these cases there is opportunity for difference of opinion, but it seems to the writer that Mr. Hitchcock's decision in such cases should be accepted without further question in all instances in which he has first designated the type.

There are a few species which require transposition of names, as for example, Cenchrus tribuloides L., the type of which proves to be the same as C. macrocephalus (Doell) Scribn.; the plant which has mostly been known under the name tributoides should bear the name $C$. carolinianus Walter; the study brings out a number of cases in which priority requires the acceptance of earlier published names than those in current use.

It has been perhaps widely assumed that most of the species of the older authors were more comprehensive in including slightly different races than those of recent writers. In some instances this is doubtless true, but in many others the species conception was apparently broad only because the describer had but a single specimen, or at best but few to base an opinion upon. Linnæus proposed some species on specimens which have been regarded by some modern authors as belonging to the same species, the differences being so slight, while on the other hand he some- 
times included widely different species in a single one; as a matter of fact, the lines of demarkation between species have usually been matters of opinion and judgment, and we have had and presumably always shall have, authors who will take broad or narrow views. This being the case, the necessity of determining in some way the absolute types of species is becoming more and more apparent, and such a work as the one now reviewed is a valuable contribution to taxonomic literature.

The type specimens of some species could not be found by Mr. Hitchcock, and presumably some of these have been lost; in such instances he has been obliged to base his conclusions upon the original descriptions; three of the species described by Swartz are those apparently preserved without types. If, in such cases we could be sure that the types do not exist, it seems to the writer that it would be advantageous to designate some other specimen as an artificial type, taking all possible care to select such a specimen from the characters assigned in the original description, and from as near the type locality as possible.

A list of new names and those replacing names in current use is appended.

\section{N. L. Britton}

\section{DR. JOHN B. TRASK, A PIONEER OF} SCIENCE ON THE WEST COAST

Dr. John Boardman Trask, who came to California in 1850, was born in Roxbury, Mass., in 1824. He died in San Francisco, July 3, 1879. His death was a public loss and was so regarded by all who were familiar with his career and varied services to the commonwealth and the community in which he lived.

Following the close of his connection with the United States and Mexican Boundary Survey, he became the first state geologist of California and was one of the illustrious eight who founded the California Academy of Sciences.

Two years and more have passed since the fine building, the home of the academy, the gift of James Lick, was destroyed by fire and earthquake. In considering that memorable event with its various tragic incidents and the loss of the library and collections, there arise from the ruins remembrances of other and earlier days, recollections of that little coterie of eight men who came together on the sixteenth of May, 1853, and organized the first society of natural history west of the Mississippi River-an event in its way equally noteworthy, though lacking the spectacular elements of the April disaster.

Soon after my arrival in California in June, 1858, I became acquainted with most of these pioneers in science, and with some of the earlier recruits who joined the little squad of charter members. Of these latter and their associates ${ }^{1}$ it may be said, without injustice to any, that Dr. Trask, by virtue of his genial qualities, untiring energy and allaround ability, was the leader, closely followed by Dr. Albert Kellogg, of precious memory, who in the new environment of his adopted state reveled amid the multifold glories of field and forest and lived, as it were, in a botanical paradise."

That these men and their fellows were regarded in those strenuous hurly-burly days of the "gold fever," as akin to cranks, pottering with their shells, and bugs, and posies, was not an unnatural thought to the average man, hustling for the "almighty dollar" or rather for the "golden nugget." However

${ }^{1}$ Dr. William P. Gibbons, one of the founders, described several species of fishes. Among the very earliest members were Dr. H. H. Behr, entomologist and writer on the Lepidoptera, etc.; Dr. W. O. Ayres, ichthyologist; Hiram G. Bloomer, botanist, and Col. Leander Ransom and Dr. Arthur B. Stout.

"Whoever has read Dr. Kellogg's " Forest Trees of California," published in the Second Annual Report of the State Mineralogist of California, 1880-2, will readily admit the propriety of these words. The plants described by him number over 300. A complete list carefully sought from all sources was published by the Academy in 1885 in the form of a Bulletin. Dr. Kellogg died on the 31st of March, 1887, and was buried in Mountain View cemetery near Oakland. 